\title{
Integrated Approach for Sustainable Hydropower Development in the Mekong River Basin
}

\author{
Pham Ngoc Bao ${ }^{1}$, Bijon Kumer Mitra ${ }^{1} \&$ Tetsuo Kuyama ${ }^{1}$ \\ ${ }^{1}$ Institute for Global Environmental Strategies (IGES), Hayama, Kanagawa 240-0115, Japan \\ Correspondence: Pham Ngoc Bao, Institute for Global Environmental Strategies (IGES). 2108-11 \\ Kamiyamaguchi, Hayama, Kanagawa 240-0115, Japan. E-mail: ngoc-bao@iges.or.jp
}

Received: January 5, 2017

Accepted: January 20, 2017

Online Published: February 9, 2017

doi:10.5539/enrr.v7n1p60

URL: http://dx.doi.org/10.5539/enrr.v7n1p60

\begin{abstract}
This paper analyses roles of integrated approach to establish a regional mechanism for sustainable hydropower development in the Mekong River Basin. Based on a critical review of the current trend of hydropower development, it argued that existing approach of uncoordinated Mekong mainstream hydropower development cannot ensure sustainable development; rather it causes negative impacts on food security, livelihoods, biodiversity, and ecosystem across the river basin, especially countries in Lower Mekong Basin (LMB), including Cambodia, Thailand and Vietnam. As a result, it fails to bring positive net benefits at both national and regional level. Specifically, if all proposed mainstream dams are constructed and fully operated, Lao PDR is the only economically winner of billions USD after 20 years, while Thailand, Cambodia, and Viet Nam are losers, and total net value will be minus 275 billion USD. Early recognition of the "nexus" interactions amongst hydropower development and cross-border food security, water security and livelihoods can minimise the risk of diplomatic conflicts and social unrest, and is only enabled when member states are willing to divert high-level government priorities from national interests to transboundary interests, as implementing the nexus approach throughout the river basin could contribute to reducing trade-offs between hydropower development and basin-wide socio-economy, and increase synergies through implementation of benefit-sharing mechanisms towards a win-win outcome. It recommends strengthening the Mekong River Commission via bolstered resources and coordinating authority, and encourages China to participate as a full member. It also argues that transboundary Environmental Impact Assessments (EIA) of river projects should be conducted to reflect the synergic and trade-off nexus effect across the whole river basin.
\end{abstract}

Keywords: energy, food, hydropower development, Lower Mekong Basin, nexus, water

\section{Introduction}

While the Paris Agreement gives a strong message that world is entering in a new low-carbon era, renewable energy including hydropower will play a vital role in order to achieve the ambitious targets that set out in this universal agreement. In general, hydropower is considered as a clean source of energy, as it burns no fuel and does not produce greenhouse gas (GHG) emissions, other pollutants, or waste associated with fossil fuels or nuclear power. The International Energy Agency (IEA) (2010) projected that global hydropower production might grow from nearly $75 \%$ in 2007 to roughly $85 \%$ by 2050 under a business-as-usual scenario. Despite hydropower being the preferable clean energy resource, particularly in a region where there is huge potential for hydropower development, the potential negative impacts on the environment due to the construction of hydropower plants may have huge tolls on food security, water security and livelihoods.

Although hydropower development is inextricably linked with food security, water security and livelihoods, however, most of the decision-making processes work in a fragmented and isolated way. Poor sectoral coordination and institutional fragmentation have triggered an unsustainable use of resources and threatened the long-term sustainability of national and regional water, energy, and food security, which are considered 3 major pillars in the newly approved Sustainable Development Goals (SDGs). This narrowly single sectoral planning approach can also create problems in international river basins, where critical decisions on upstream hydropower development, for instance, that ignore basic human needs may well involve economic benefits, but at the expense of irreparable ecosystem damage as well as loss of water and food security further downstream. 
This is particularly true for the Mekong River Basin, where is home to 80 million people in the Southeast Asia. Hydropower dam development for energy along the mainstream area is becoming one of the major "drivers" of the development in the region (Grumbine et al., 2012). But uncoordinated hydropower development may change water flow patterns, loss of soil nutrients, inundation of agricultural land and damage to migratory fisheries due to uncoordinated development of hydropower plants in upstream countries that would have negative impacts on food security, livelihood, biodiversity, and the ecosystem (Piman et al. 2013; Cronin and Hamlin 2012). Construction of a series of dams in the upstream part of the river, named as the Lancang River in China, has already altered river flow, fish production and affected communities along the Lower Mekong Basin (LMB). Pornrattanaphan (2004) claimed that construction of the Mawan dam in China would be responsible for a $25 \%$ reduction in the annual mean minimum discharge. Construction of dams upstream would also responsible for decreasing suspended sediments in the Mekong system (Fu \& He 2007). The situation could get much worse if a planned cascade of mainstream dams is constructed in the LMB. For instance, the construction of Xayaburi dam in Lao PDR will be responsible for reducing nutrient rich alluvial sedimentation in the Mekong Delta from 26 million tonnes to 7 million tonnes annually (VNA, 2011). The unbalanced net economic benefit and disappointing negative impacts due to uncoordinated development of hydropower plants would also raise geopolitical tension in the region.

Based on an extensive literature review, this study has investigated critical cross-sectoral impacts of existing uncoordinated hydropower development in Mekong River Basin. Finally, this paper proposed appropriate mechanisms for introducing an integrated framework to integrate "nexus" interactions into the planning and decision-making process for hydropower development in Mekong River Basin, which could facilitate in promoting the synergies and minimizing the trade-offs between the areas or sectors to optimize resources management.

\section{Roles of Hydropower-Based Regional Power Trading in Regional Energy Security}

Over the last 15 years, in order to address the growing demand for energy, the regional trade in electricity has become an integral part of the electricity supply plan in the Mekong countries. According to ADBI (2013), 59 export-oriented hydropower projects have been under construction and implementation. However, none of the projects were developed based on a truly regional power market, and instead were based mainly on bilateral cooperation. Most of the export-oriented hydropower projects have been planned and established based on import commitments between Thailand and Viet Nam and countries such as Lao PDR and Myanmar, which have abundant hydropower potential. Lao PDR is the largest volume exporter as well as the most competitively priced supplier. Meanwhile, Thailand is one of the main investors in hydropower in Lao PDR. The Government of Lao PDR (GoL) has committed to supplying 7000 MW to Thailand by 2020 (GoL, 2016). The controversial USD3.6 billion Xayaburi dam in Laos, if completed, will be the first mainstream dam on the lower Mekong, funded by Thai banks and developed by a Thai construction company (Matthews, 2012). Other than bilateral cross-border trading of electricity, Lower Mekong Basin (LMB) countries, including Laos, Cambodia, Thailand and Viet Nam, have also exhibited political willingness to establish interconnection arrangements for electricity via the ASEAN Power Grid through adoption of "ASEAN Vision 2020" at the Second ASEAN Informal Summit in 1977 (ASEAN Centre for Energy, 2013). The ASEAN Power Grid is anticipated to provide a secure regional energy network and promote win-win economic relationships in the region.

Economic development is one of the main goals of current hydropower-based regional integration in the GMS. However, policy limitations on the mitigation of social and environmental impacts represent one of the major challenges to hydropower-based energy security in the region. Under current development plans it is predicted that the region will experience negative social and environmental impacts, particularly in downstream countries like Cambodia (ICEM, 2010; Zaffos, 2014), which are directly relevant to the water-food-energy nexus.

Over the past few years, investors and developers, mainly from Chinese and Thai companies and banks, have submitted proposals for 12 hydropower projects for the LMB mainstream, 10 in Lao PDR (including two of which are on the Lao-Thailand reaches of the mainstream) and two in Cambodia (Figure 3). It is predicted that introducing these dams on the Mekong will severely impact fish migration and reproduction along this world's largest inland fishery. The Mekong River Commission's (MRC) three-year study released in 2015 found that the proposed 11 mainstream dams, if constructed, will wipe out approximately half of all its fisheries, severely impacting the communities relying on fishing for protein and/or employment (Kinna, 2016). 


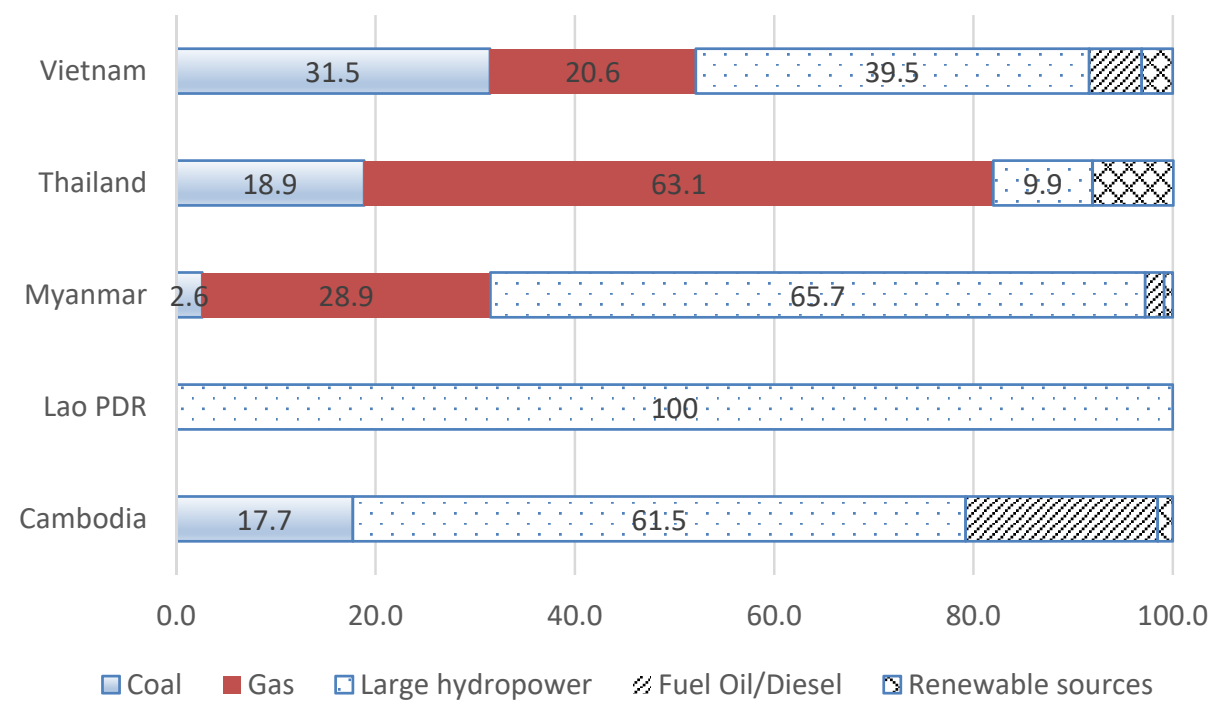

Figure 1. Share of power generation outputs of the countries in GMS in 2014 (Source: IES, 2016)

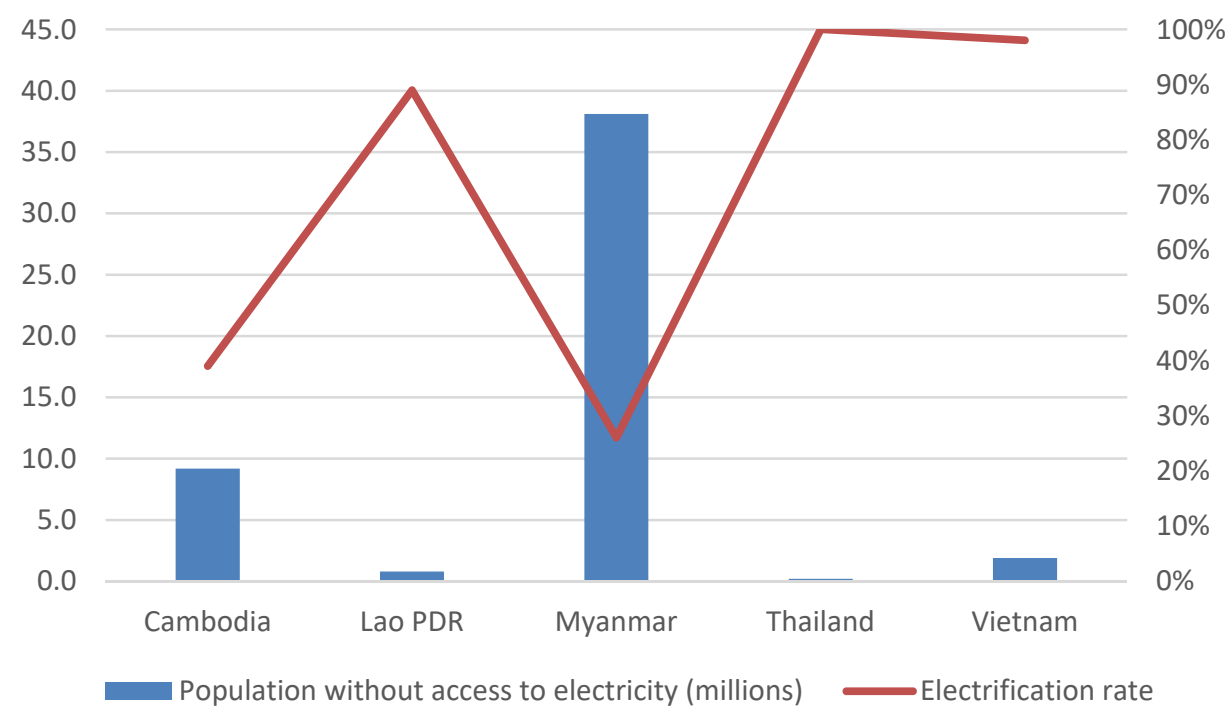

Figure 2. Population without access to electricity vs. Electrification rate in Mekong countries

(Source: IES, 2016)

\section{Scientific Evidences of Transboundary Environmental Impact of Mainstream Hydropower Dam Construction}

Although hydropower has been acknowledged as the cheapest clean energy technology, narrow-scoped sectoral planning may have significantly negative impacts on water and food security in the region and intensify upstream-downstream conflicts.

It is clear that the waters of the Mekong are profitable for those who see development in terms of energy production. However, hydropower development may create negative impacts on food security, specifically on the fisheries and agriculture sectors of the downstream countries such as Viet Nam and Cambodia. The ongoing construction of Xayaburi and Don Sahong hydropower dams in Lao PDR represents a typical example of hydropower projects, as an important part of Lao government plans to get more revenue from electricity exports, but it will create a significant negative impact on the environment and on the poor populations of Cambodia and Viet Nam. According to Vannarith (2012), if the Xayaburi dam were to be constructed in the mainstream Mekong River, the primary food source (fish) of $80 \%$ of Cambodia's population would be affected. The Tonle 
Sap lake area, which represents $60 \%$ of Cambodian inland fisheries, would be most seriously affected (Matsui et al., 2006). Consequently, the livelihood of 1.2 million people in the areas surrounding Tonle Sap Lake would be under threat. Meanwhile, the Mekong delta in Viet Nam was hit by the most serious drought in the last 90 years in March and April 2016, due to dam construction in the upstream countries. The situation is so serious that the Government of Viet Nam had to request China to release water from its reservoirs to let water flow to the lower course. Unfortunately, there were only 200 million cubic meters of water, which went through three countries, Myanmar, Laos and Cambodia, all of which need water. Therefore, the volume of water reaching Viet Nam was very modest (Vietnamnet, 2016).

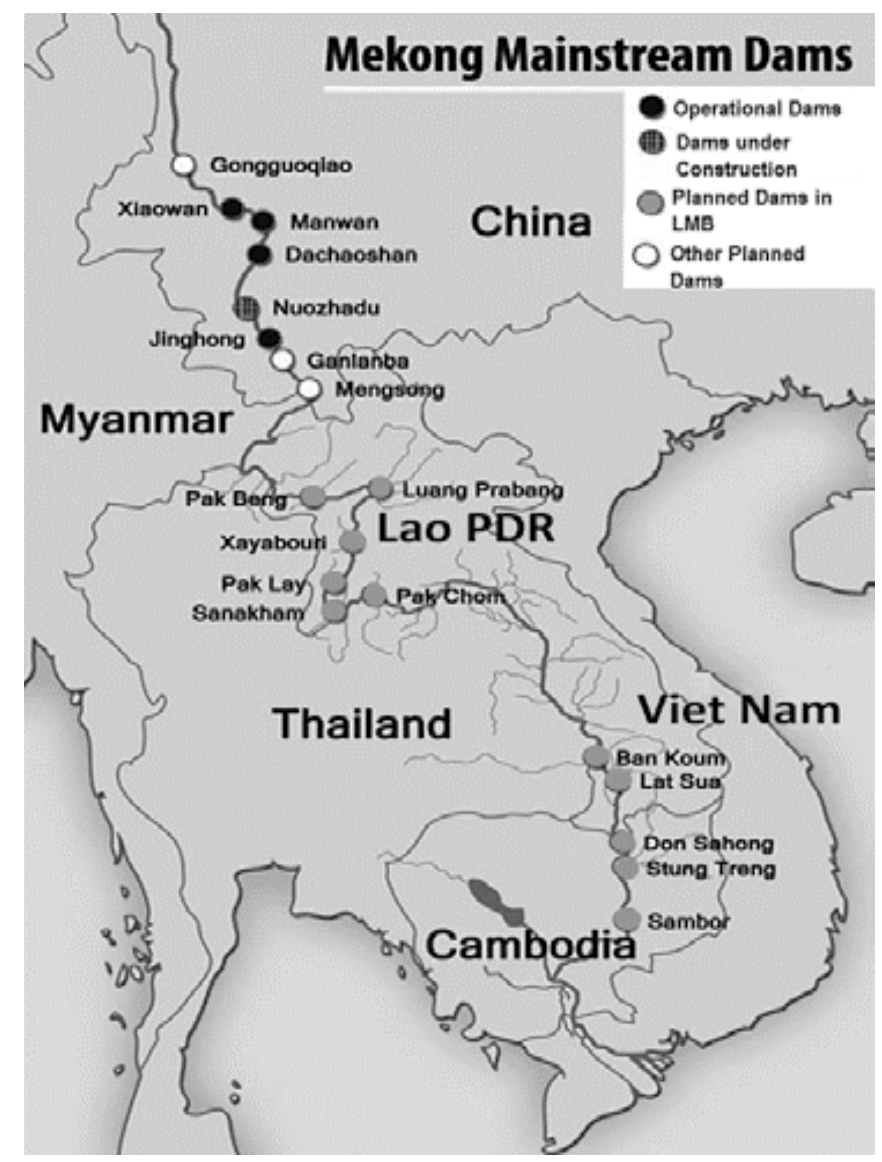

Figure 3. Thick cluster of dams constructed or to be constructed along the Mekong River, including 11 proposed dams on the mainstream (Source: Modified from Cronin \& Hamlin, 2012)

A critical review of the latest Environmental Impact Assessment (EIA) Report of the Xayaburi dam by the World Wildlife Fund (WWF) reported that the EIA not only fails to address major concerns such as impact on fish species, aquatic habitats, and targeted species for fish passage design but also fails to address transboundary impacts (WWF, 2011). Although this dam is built on a transboundary river basin, the EIA was carried out based on the national EIA requirements and the potential impacts were only assessed to a distance of $10 \mathrm{~km}$ downstream, completely ignoring downstream neighbouring countries (International Rivers, 2014). As a result, the report faced strong objections from neighbouring countries and NGOs, who all requested a more comprehensive study and assessment of transboundary and basin-wide environmental impacts, including a cumulative impact assessment. The International Rivers Network criticised the construction of Xayaburi dam in a recent report and claimed that Lao PDR had gravely violated the 1995 Mekong Agreement (Herbertson, 2013). Despite this strong opposition, the Government of Lao PDR declared that $30 \%$ of construction work had been completed and dam construction would continue according to plan (Phnompenh Post, 2014) — an example of private sector actors taking advantage of government agencies to push through unsustainable projects that would not be acceptable elsewhere (WWF, 2014). 


\begin{abstract}
BOX 1: China factors and its impacts on the Mekong's mainstream
It would be insufficient and incomplete to discuss hydropower dams on the Mekong's mainstream without mentioning the roles of China. Rising demand for energy led to China's decision to construct a cascade of dams on the upstream section of the Mekong River, comprising eight large dams under construction or completed. China has also made plans for a further 12 large dams on the Lao, Lao-Thai, and Cambodia stretches of the Lower Mekong mainstream.
\end{abstract}

Currently, four mega-sized dams have been constructed on the Langcang Jiang in Yunnan Province; the remaining four are in various stages of planning and construction. All of these dams have been proposed and constructed without consulting downstream neighbors or sharing data about water flows (Arias et al., 2014). Construction of this series of dams in China has already altered river flow, fish production and affected communities along the Lower Mekong Basin (LMB). Kummu and Varis (2007) estimated that the major Chinese reservoirs on the upper Mekong (Lancang) will have sediment trapping efficiencies between $66 \%$ and $92 \%$, with large potential impacts for downstream areas. This situation could significantly worsen if a planned cascade of mainstream dams goes ahead in the LMB. A Strategic Environmental Assessment (SEA) conducted by MRC experts estimated that the livelihoods of nearly a million people will be at risk due to the impacts of these dams alone. The dams will also reduce sediment flow from China by about $22 \%$ from normal levels, leading to huge impacts on food security in the downstream countries, as overland floods deposit massive amounts of nutrients along with the sediment. Whether Yunnan dams were planned to facilitate mainstream dams on the Lower Mekong cannot be determined due to lack of sufficient and useful data on the critical design characteristics of the Yunnan dams and how these dams will be operated (Cronin and Hamlin, 2012). Consequently, the downstream countries can only make assumptions based on the known physical characteristics and configurations of the dams. Thus, investments on downstream dam construction will face huge risk and uncertainty. Cronin and Hamlin (2012) suggest that the four LMB countries should adopt a more unified stance and demand greater transparency and due consideration of downstream interests in how China operates these upstream dams. The ideal approach to regional cooperation for environmentally sustainable management, including hydropower development, should involve all six countries of the Mekong Basin, including China and Myanmar, through participation in the MRC.

At the Second Mekong Summit held in Ho Chi Minh in April 2014, both Cambodia and Viet Nam, as well as donor agencies continued to voice their strong concerns over the project (Marwaan, 2014). Despite this fact, the construction work on the Xayaburi and Don Sahong Dams in Laos is still progressing at a rapid pace, amid urgent questions about its impacts on the food security and livelihoods of those near the site as well as up and downstream the Mekong River. According to Thanhnienews (2016), around mid-June 2016, the United Nation's Special Procedures echoed concerns over the impacts of the Don Sahong Dam in a report to the UN Human Rights Council. The report highlights the project's potential violations of local people's rights to adequate food and housing, information and participation, and the rights of indigenous people.

According to ICEM (2010), construction of mainstream dams on the lower Mekong is estimated to cause colossal losses in the fisheries sector, equivalent to USD 476 million /year, a loss of 54\% of riverbank gardens, and a reduction in nutrient loading, requiring an estimated USD 24 million/year to maintain the productivity of floodplain agriculture. ICEM (2010) also estimated that by 2030 the loss of fish production is expected to be $210,000-540,000$ tonnes or $10-26 \%$ of the year 2000 baseline with no LMB mainstream dam scenario.

The above study also forecasted the fish production losses under different scenarios, including no LMB mainstream dam construction, 6 dams to be constructed in the upstream cluster, 9 dams to be constructed in the upstream and middle cluster, and all 11 LMB mainstream dams to be constructed (Figure 4). In case if 6 dams were built upstream of Vientiane, a loss ranging between 270,000 and 600,000 tonnes or $13-29 \%$ is expected compared to the situation in 2000. If 9 mainstream dams were operating upstream of Khone Falls, the loss in fish resources would amount to $350,000-680,000$ tonnes or $17-32 \%$ compared to the 2000 baseline. Meanwhile, if all 11 mainstream dams are constructed, the total loss in fish resources would increase to $550,000-880,000$ tonnes or $26-42 \%$ compared to the 2000 baseline, meaning a 340,000 tonne fisheries loss would be the direct result of mainstream dam construction (Figure 4). This annual loss represents $110 \%$ of the current total annual livestock production of Cambodia, under the 11 main stream dam scenario. 


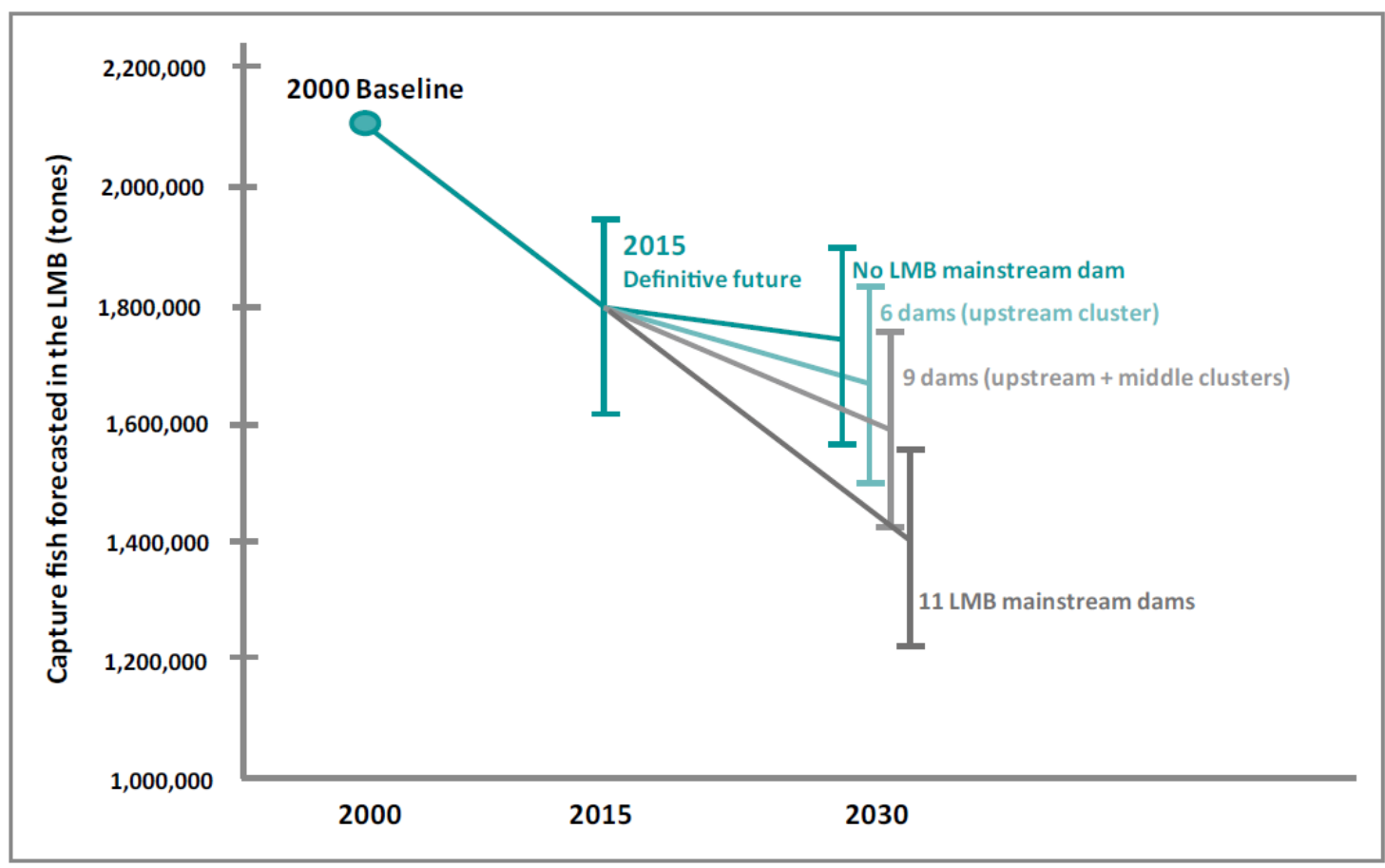

Figure 4. Potential incremental impacts of LMB mainstream dams on fish production basin-wide

(Source: ICEM, 2010)

From the discussion above, it is envisioned that if the planned mainstream dams go ahead without due consideration and comprehensive assessment of their impacts for the whole basin, food security, livelihood, soil fertility, biodiversity and ecosystem will all be heavily negatively affected.

Moreover, impacts of hydropower development are not limited to mainstream dams and are also caused by dams constructed on the Mekong's tributary systems. One of the most important tributary systems of the Mekong is the " $3 \mathrm{~S}$ " river basin, comprising the Sekong, Sesan and Srepok River Basins, accounting for about $17 \%$ of the Mekong's annual flows. Due to the growing demand for electricity supply in Viet Nam and Cambodia, an increasing number of hydropower projects in the $3 \mathrm{~S}$ river basin are being considered, with more than 20 hydropower projects already built or under construction, and 26 additional dams slated for construction in the near future (Grimsditch, 2012). Recently, a plan for the construction of the 420 MW Lower Sesan 2 hydropower dam and 375 MW Lower Sesan 3 hydropower dam in Cambodia (invested in by Chinese companies) were approved by the Government of Cambodia (Cambodiadaily, 2013). Ziv et al. (2012) reported that the Lower Sesan 2 dam alone would cause a 9.3\% drop in fish stocks basin-wide, threaten over 50 fish species, alter the Mekong hydrological low flows and lead to reduced sediment flows of approximately $6-8 \%$.

\section{Winner and Loser of Current Practice of Hydropower Development?}

Energy cooperation as part of the GMS Economic Cooperation Programme has been identified as one of nine areas of sub-regional cooperation. Recent estimates of energy resources in the GMS include about 229 gigawatts $(\mathrm{GW})$ of potential hydropower generation annually, as well as proven reserves of about 1.2 billion cubic meters of natural gas, 0.82 billion tonnes of oil and 28.0 billion tonnes of coal. Despite this, the energy reserves are unevenly distributed throughout the sub-region. Lao PDR, Myanmar, Viet Nam, and the two PRC provinces in the GMS account for about $94 \%$ of the hydropower resources (ADBI, 2013). The peak power demand in the GMS, which stood at about $83 \mathrm{GW}$ in 2010, is expected to more than triple to about $277 \mathrm{GW}$ by 2025 (ECA, 2010).

In view of sharing benefits from diversifying energy resources to meet various demands across the region, energy cooperation in GMS has so far focused on regional power trade and grid interconnections. Based on the current design, if all proposed mainstream dams are developed, they could significantly increase generated power in the region and represent up to $14,697 \mathrm{MW}$ or $23-28 \%$ of the national hydropower potential of the four LMB countries and $5-8 \%$ of the total hydropower potential in the GMS region. They would also provide economic benefit, but mostly to Lao PDR. It is expected that Lao PDR would receive $70 \%$ of export revenues 
(USD 2.6 billion/year) generated by the mainstream dams, with Cambodia receiving 30\% (USD 1.2 billion/year) Lao PDR would benefit most, primarily because of the number of projects located there (ICEM, 2010). All of these proposed dams are commercial projects that would be constructed, operated and owned by foreign investment companies. To a certain extent, this was brought about by slackened environmental controls offered by some countries as an inducement for foreign investment (King et al., 2007).

In contrast with private companies and banks, multilateral financial agencies such as Asian Development Bank and the World Bank have confirmed they would not support or invest in hydropower projects on the mainstream Mekong because doing so would grossly violate their guidelines for environmental and socioeconomic impacts (Thanhniennews, 2011). According to MRC (2011), the 11 proposed dams in LMB would turn 55\% of the Mekong River into reservoirs and lead to estimated agricultural losses topping USD 500 million per year, slashing the average protein intake of Thai and Lao populations by $30 \%$.

A study conducted by Portland State University \& Mae Fah Luang University demonstrated that under most scenarios, especially under the most adverse revised assumptions for an 11-dam scenario, Lao PDR is still a USD 15.5-billion winner after 20 years, while Thailand, Cambodia, and Viet Nam are losers by USD 129.9, 110.3, and 50.7 billion, respectively (Figure 5) (Costanza et al., 2011).

Lao PDR, together with power-importing countries and investors, could play a role in reducing the risk of total net economic loss in the region due to construction of uncoordinated mainstream dams by utilising the tributaries instead, and could also consider the ecological and socioeconomic consequences, as well as the possible mitigation measures until appropriate solutions for sustainable development of a mainstream dam of mutual benefit to riparian countries are identified. Adopting this stance could also encourage multilateral financial agencies to invest in hydropower projects, as occurred in the Nam Theun 2 hydropower dam in Lao PDR tributary, which secured international investment via multilateral development banks (including World Bank, Asian Development Bank, European Investment Bank, and Nordic Investment Bank), export credit agencies, bilateral financing agencies, international commercial banks, and Thai commercial banks. An extensive review of hydropower development in Lao PDR indicates that the country has 18,000 MW of hydropower potential - without the need for any mainstream dams. Only 15\% of the country's hydropower potential has been developed over the past 40 years (GIZ, 2014). As a result, Lao PDR has a huge hydroelectric capacity derived from its tributaries; in fact, the combined capacity of these plants exceeds demand. By 2020, the country's electricity demands will reach 2,500 MW, which is still only $14 \%$ of the hydropower potential (excluding mainstream dams).

Therefore, construction of dozens of proposed mainstream dams on the Mekong River may improve electricity supply and potentially boost economies in the region, but unfortunately the net economic benefits of dam construction under most scenarios would be positive only for Lao PDR, while other countries including Viet Nam, Thailand and Cambodia could experience total net economic losses (Costanza et al., 2011). In addition, concerns have intensified over the potential cumulative impacts of these mainstream dams on the environment, fisheries, and people's livelihoods. It is forecasted that the construction of these mainstream dams would displace 100,000 people and 2.1 million others would be at risk of indirect negative impacts. Dams would turn more than half of the length of the main river into reservoir characterized by slow-moving water conditions, thereby increasing the risk of water-borne diseases (Grumbine et al., 2012). This situation-one of lop-sided economic benefit versus negative impacts due to uncoordinated development of hydropower plants in upstream countries - could raise geopolitical tensions in the region (see Fawthorp, 2013).

Consequently, Lao PDR should consider delaying construction of new mainstream dams until a more comprehensive transboundary impact assessment is performed. In this case, importing countries like Thailand and investors could play a vital role by encouraging Lao PDR to harness hydropower potential from the tributaries.

Alternatively, WWF (2014) suggested that some other existing less destructive and environmentally more sustainable electricity generation and hydropower options could be used. Employing user-friendly assessment tools such as Hydropower Sustainability Assessment Protocol (HSAP) or the Rapid Basin-wide Sustainability Assessment Tool (RSAT) can help to incorporate regional factors into the project site, design and operation. 


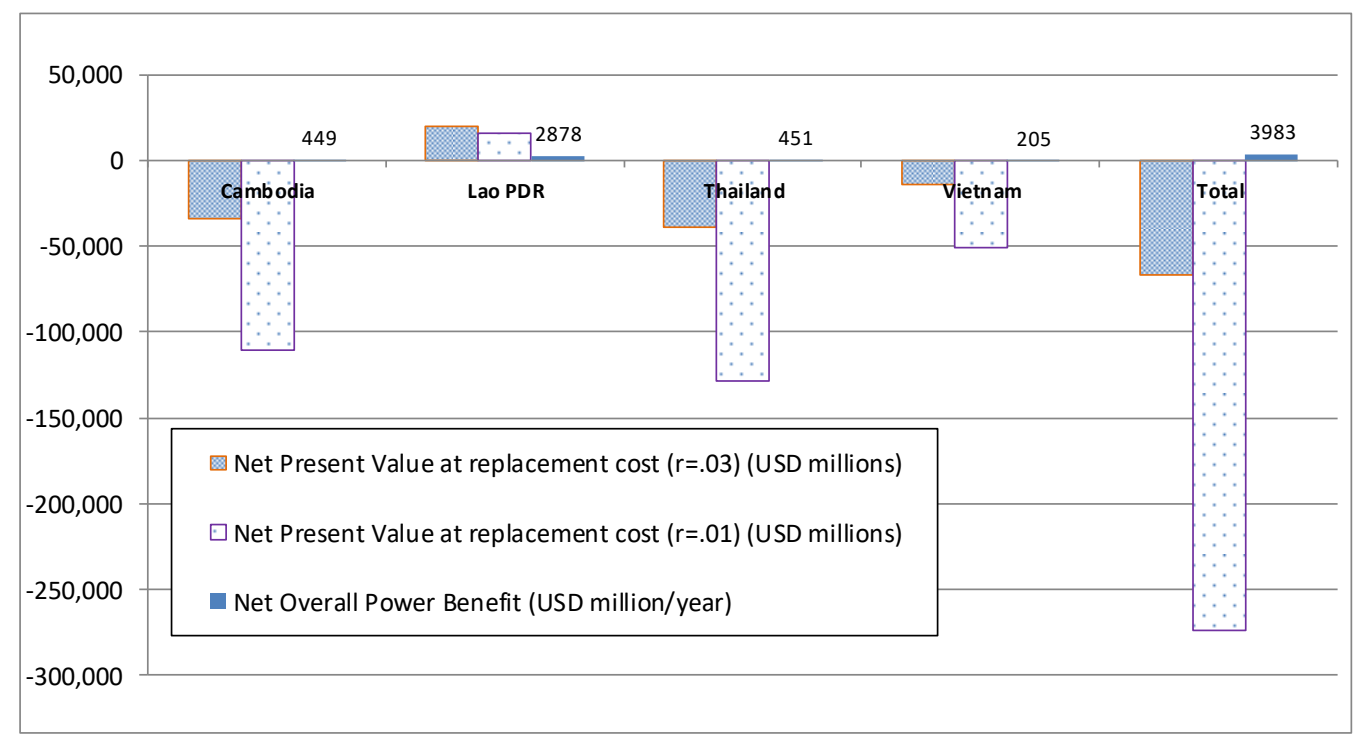

Figure 5. Net economic benefits of hydropower dam construction on Mekong River (Source: Costanza, et al., 2011)

\section{An Integrated Framework to Integrate "Nexus" Interactions into the Planning and Decision-Making Process for Sustainable Hydropower Development in Mekong River Basin}

Resource scarcity, which emphasizes water, food and energy as human basic needs, is one of the most urgent shared concerns in the world as well as in the region (Griggs, 2013). Moreover, water, food and energy have moved to the top of the global agenda following the food and energy price increases that started in 2007. Addressing the water, food and energy nexus is considered increasingly important for transparently and equitably meeting increasing global demand without compromising sustainability (Lele et al., 2013). Leaders around the world are increasingly recognizing the importance of the water-food-energy nexus perspective as a conceptual framework to facilitate integrated planning and decision-making for the post-2015 development agenda. The 2030 Agenda for Sustainable Development was developed with a strong emphasis on synergies and innovative approaches so that achieving one goal would not be at the expense of another, and that co-benefits could be found in the nexus approach.

In the "Global Trends 2030" report (NIC, 2012), the US National Intelligence Council described the interconnected nature and risks in water, food, energy supply security as a "megatrend" that will gain global momentum in the near future. Actions or solutions for one single resource or sector may bring positive or negative impacts on the other two. Disconnected approaches and silo-like thinking are more likely to make matters worse and risk serious unintended consequences. Therefore, there is a strong need to establish an enabling policy framework for managing these nexus challenges.

The nexus approach requires a major shift on the decision-making process towards (i) taking a holistic view to manage the critical resources of water, food and energy through an integrated, collaborative and participatory approach; (ii) developing institutional mechanisms to coordinate the actions of diverse actors; and (iii) minimizing potential sectorial trade-offs and strengthening synergies between the sectors to optimize resources management.

Figure 6 suggests an integrated framework to integrate goals, strategies and policies within the three sectors, and to facilitate the move from single-sectoral to cross-sectoral planning approach. As can be seen in this figure, there are four major pillars in this framework, which are (i) joint visioning and shared goals among the three sectors; (ii) coordination of sectoral strategies; (iii) regulations, policy and incentive instruments; and (iv) regulating or promoting nexus smart investment.

- Step 1. Joint visioning and shared goals: there is a strong need to establish appropriate mechanisms for sharing policy goals, joint visioning, and strengthening both horizontal and vertical integration and consistency among the three sectors and relevant stakeholder groups. It aims at minimizing both cross-sectoral and transboundary conflicts, and maximizing synergies while achieving the goals and visions in each sector. It is also essential to mainstream the nexus perspective into both national and 
regional development planning and implementation process, as well as strengthening institutional capacity for all relevant stakeholder groups for better understanding of the dynamics and interlinkages among the sectors. Resolving any potential policy conflict and inconsistency considering both cross-sectoral and transboundary aspects, and promoting mutually reinforcing policies for achieving multiple goals are also vital.

- Step 2. Coordination of sectoral strategies: coordination of sectoral strategies is crucial for promoting synergies, minimizing trade-offs and achieving optimal alignment of the strategic objectives. It is also necessary to examine these strategies with a nexus lens to give support in identifying trade-offs and options for mutually reinforce adaptive strategies, and ensuring sectoral coherence.

- Step 3. Regulations, policy and incentive instruments: regulations, policy and incentive instruments should be reoriented towards promoting water and energy saving, high-efficiency, water and energy smart technologies, and away from the policy distortion towards water and energy intensive food production or water intensive energy production, etc. Ensuring both policy and governance coherence is necessary. One good example of these incentives is the benefit-sharing mechanism.

- Step 4. Regulate/promote nexus smart investment: it is important to regulate or promote unsustainable practices or unsustainable use of resources, and promote technological and institutional innovations and smart nexus investment. One example is unsustainable practice of freely or overuse of groundwater for irrigation or food production. In addition, it is also critical to raise public awareness for responsible resource use, and engage multilevel and all relevant stakeholder groups in the planning process for resource use. Investments in water and energy saving technologies, and in renewable energy options should be encouraged. Effective strategies should be designed to attract investment to exploit win-win opportunities, such as production and use of renewable energy (e.g. hydropower, solar-powered water pumps for irrigation and production of biogas from animal manure).

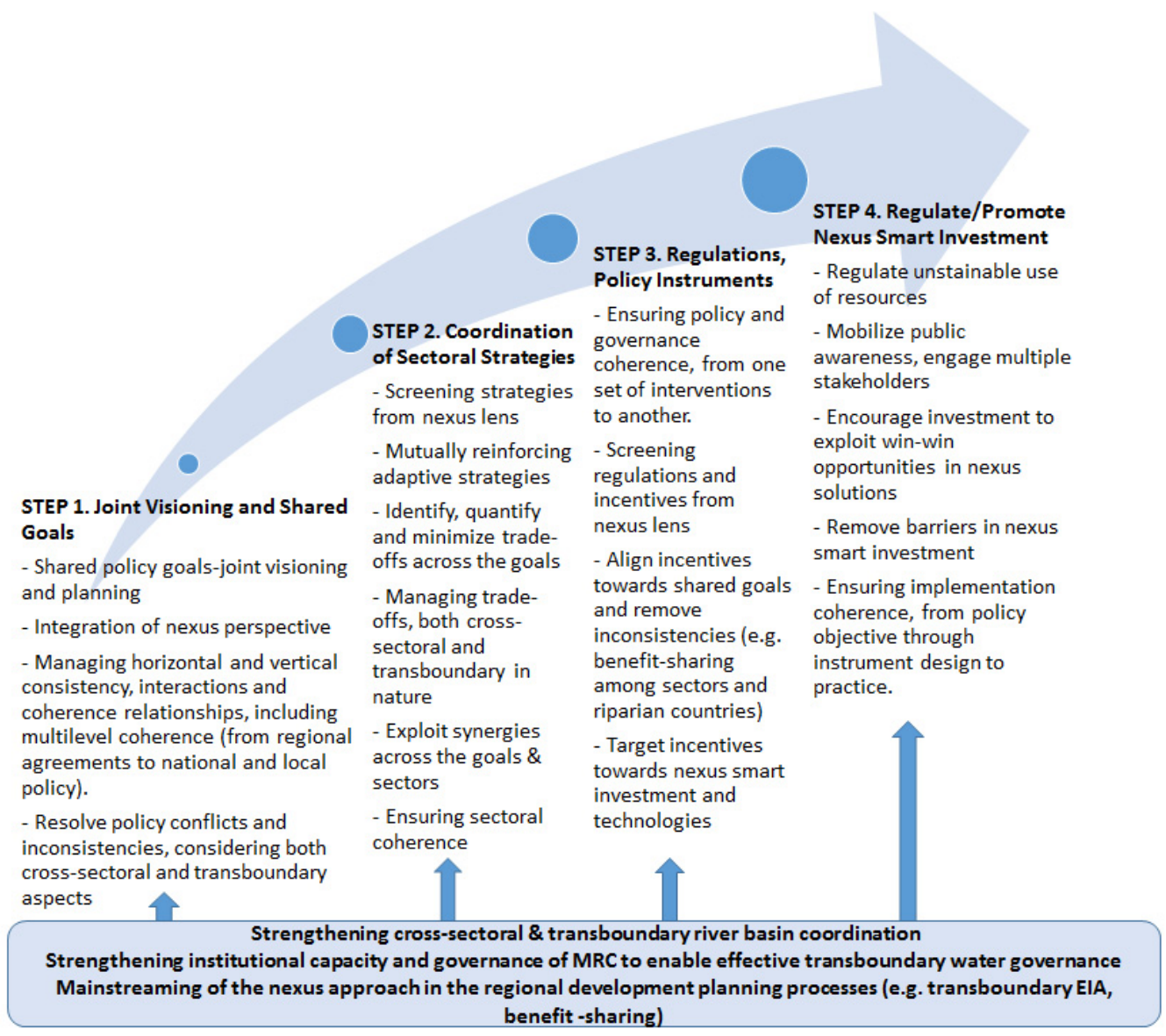

Figure 6. An integrated framework to integrate "nexus" interactions into the planning and decision-making process for sustainable hydropower development in Mekong River Basin

(Source: Author's modification from Rasul, 2016) 
By introducing this framework, it will offer the potential of providing decision makers with necessary information during the planning and decision making process for sustainable development pathways. It also supports more effective negotiations, by enabling relevant countries and sectors to see more clearly their interests coincide, where they diverge, and how they might resolve or narrow down their differences. This framework not only can be applied within water, food, energy sector, or within Mekong River Basin, it can also be utilized by decision makers of other sectors or other river basins in Asia such as Ganga and Indus River Basins in South Asia, although some appropriate adjustments might be required depending on its political and regional contexts.

\section{Suitable Policy Mechanism for Mainstreaming Nexus Perspective in Developing Mainstream Dam in Mekong}

\subsection{Benefit Sharing Among Sectors and Riparian Countries}

The earlier sections clearly demonstrate that heavy infrastructure development on the mainstream by one riparian country would affect downstream countries by changing the pattern of water flow, reducing sediment transportation, and reducing fisheries stocks. While some predict rising water conflicts and potential war (Klare, 2001), others have suggested that water may serve as a catalyst for cooperation (Wolf et al., 2003). In this context, benefit sharing has been suggested as a sensible strategy to move towards cooperative use of international waters. It is argued that benefit sharing from water facilitates engagement of riparian countries in development and management of transboundary water bodies, equitable distribution of transboundary benefits from water cooperation, and win-win options instead of potentially conflicting water sharing (Rossouw, 2010). According to Kumar et al. (2010), transboundary benefit sharing is based on the presumption that a common management of water resources generates net benefits compared to unilateral development of water resources.

In more detail, the benefits provided by water cooperation are (i) benefits to the river (protecting watersheds, conserving aquatic and riverine terrestrial biodiversity, preserving soil fertility, preserving water quality, and maintaining natural buffering capacity of the river stream); (ii) benefits from the river (food production, and power generation); (iii) reduced costs via shift of policy from dispute to cooperation and ideological change from energy-food sufficiency to energy-food security benefits due to cooperation on transboundary river; and (iv) catalysing benefits beyond the river such as integration of regional infrastructure, markets and trade (Sadoff and Grey, 2002).

Table 1 shows that a number of benefit-sharing mechanisms, including monetary benefit sharing (e.g., revenue sharing, property tax, preferential rates, and securing income) and non-monetary benefit sharing are in use in different parts of the world. Although most benefit sharing mechanisms have been established for domestic impact, a few can be seen in transboundary river basins as well-such as in Senegal, Mali and Mauritania, who have agreed to share developmental costs and benefits of jointly-operated common infrastructure in the Senegal River Basin using a burden-sharing formula (Qaddumi, 2008). Bilateral power-trading projects also create win-win opportunities for both participating countries, although impacts on other riparian countries are ignored.

In the Mekong River Basin, direct regional benefit sharing, especially revenue sharing, can reduce negative externalities on food and water security of downstream countries caused by hydropower development in the upstream countries. As discussed in section 3, most of the benefits from hydropower generation in LMB will fall to Lao PDR. In contrast, the livelihoods of millions of poor people and food security would be adversely affected in the downstream countries, including Cambodia and Viet Nam. In this case, transboundary benefit sharing and national-to-local benefit sharing in the framework of a nexus approach can mitigate diplomatic anxiety and contribute to sustainable development throughout the river basin. A good example of benefit sharing of hydropower development in LMB is the Nam Theun 2 hydropower project. This project is committed to providing compensation from revenue for socioeconomic development to improve living conditions, healthcare, education, access to roads, electricity, poverty reduction and environmental protection.

For motivation and sustainable cooperation, the riparian countries should agree on sharing generated benefits in a fair manner in order to optimize the basin-wide benefits. Political willingness to share benefits plays a key role for the realization of benefit sharing in the context of transboundary river basins (Sneddon, 2008). 
Table 1. Benefit sharing mechanisms under two different spatial contexts

\begin{tabular}{|c|c|c|}
\hline \multicolumn{2}{|c|}{ Type of benefit sharing mechanism } & \multirow{2}{*}{$\begin{array}{l}\text { Description } \\
\text { Revenue sharing with local or regional authorities tied to output } \\
\text { of power generation. }\end{array}$} \\
\hline $\begin{array}{l}\text { Monetary } \\
\text { Benefit } \\
\text { Sharing }\end{array}$ & $\begin{array}{l}\text { Revenue sharing } \\
\text { (e.g., in Norwegian, Colombian, Brazilian, } \\
\text { Argentina and Nepalese legislation) } \\
\text { (Source: iwawaterwiki.org; MRC, 2011) }\end{array}$ & \\
\hline & $\begin{array}{l}\text { Preferential rates } \\
\text { (e.g., in Norwegian legislation) }\end{array}$ & $\begin{array}{l}\text { Preferential electricity rates can be negotiated between local or } \\
\text { regional authorities and infrastructure operators. }\end{array}$ \\
\hline & $\begin{array}{l}\text { Property taxes } \\
\text { (e.g., in Norwegian legislation) }\end{array}$ & $\begin{array}{l}\text { Taxing of infrastructure operators based on project's property } \\
\text { value or other factor. }\end{array}$ \\
\hline & $\begin{array}{l}\text { Development funds } \\
\text { (e.g., Nam Theun 2; in Norwegian } \\
\text { legislation) }\end{array}$ & $\begin{array}{l}\text { Development funds from power sales are used to foster } \\
\text { economic development, compensate affected people and } \\
\text { conserve ecosystems in project-affected areas. }\end{array}$ \\
\hline & $\begin{array}{l}\text { Livelihood restoration, socioeconomic } \\
\text { development (e.g., Nam Theun 2) }\end{array}$ & Securing income through job creation. \\
\hline \multirow[t]{2}{*}{$\begin{array}{l}\text { Non- } \\
\text { Monetary } \\
\text { Benefit } \\
\text { Sharing }\end{array}$} & $\begin{array}{l}\text { Equitable sharing of project services for } \\
\text { community development (e.g., Vietnam) }\end{array}$ & $\begin{array}{l}\text { Households in project areas receive improved access to energy } \\
\text { services in return for having hydropower project located in their } \\
\text { area. The infrastructure project should facilitate access to } \\
\text { markets and common resources. }\end{array}$ \\
\hline & $\begin{array}{l}\text { Transboundary resource development } \\
\text { (e.g., bilateral power trading projects in } \\
\text { GMS) }\end{array}$ & $\begin{array}{l}\text { Transboundary resource development triggered by power } \\
\text { infrastructure projects could create win-win opportunities }\end{array}$ \\
\hline
\end{tabular}

(Source: Qaddumi, 2008; Rossouw, 2010; MRC, 2011).

\subsection{Enforcement of International Water Conventions and Transboundary EIA}

Maximization of indigenous energy resources to fuel economic growth is the driver of hydropower promotion in all LMB countries. However, a number of studies have demonstrated that uncoordinated dam construction in the Mekong mainstream will create huge environmental and social issues in the region (ICEM, 2010; WWF, 2014) and also threaten sub-regional power trading initiatives. For sustainability of sub-regional power trading and cooperation, environmental issues need to be addressed in national and regional energy planning and policies. Although all LMB countries have basic environmental legislation regarding EIA, none of them have specific environmental criteria for hydropower development (King et al., 2007). This lack of both environmental and social safeguard policies has been seen by certain foreign investors as an incentive to advance into hydropower projects. Therefore, adoption of a transboundary EIA framework by the LMB (and preferably the six GMS) countries will enable adoption of common environmental criteria for hydropower projects in the region.

Adoption of the 1997 Convention on the Non-Navigational Uses of International Watercourses by the United Nations General Assembly (UNWC) provided the framework for inter-state cooperation on international watercourses, but is yet to be enforced in Mekong River Commission (MRC) member states. Although all MRC member states voted for the UNWC adoption in 1997, Viet Nam is the only Mekong Basin state to accede to the UNWC so far. UNWC covers all of the generally accepted principles and procedures of international law for water, and represents the global 'rules of the game' for managing rivers shared by two or more countries. Basically, it requires basin states to (i) cooperate in good faith; (ii) prevent pollution and protect ecosystems; (iii) notify, negotiate, and consult with each other on projects that can have major impacts to the basin; and (iv) try to avoid or peacefully resolve disputes through a variety of forums (Kinna, 2016).

Another successful convention in Europe is the Convention on Environmental Impact Assessment in a Transboundary Context (informally called the Espoo Convention). The Espoo Convention acknowledged that separate political identities and national goals together represent one of the main barriers in transboundary environmental management, and even more so for transboundary river basins, where upstream states are less motivated to consider the interests and rights of downstream states. Espoo obliges parties to carry out transboundary environmental impact assessments for certain activities in initial planning stages. The success of Espoo in Europe motivated countries in other regions such as Canada and in central Asian to sign into the 
convention. Core attributes of Espoo are in the areas of transboundary impact assessments, inter-party consultation, cooperative arrangements, dispute resolution and public participation - all crucial for transboundary basin development. Introduction of transboundary EIA in the Mekong Basin under an international convention such as Espoo would help assess the adverse impacts of hydropower projects across the river basin by involving any potentially affected neighbouring countries in EIA and decision-making processes. Such assessments would aid in formulating measures to mitigate the adverse impacts across the river basin under the framework of a nexus approach. Furthermore, transboundary EIA can enhance international cooperation through better understanding of the possible trade-offs and equitable sharing of benefits. Transboundary EIA also facilitates early information sharing with potential victims and ensures public participation in decision-making so that project implementation can avoid diplomatic issues at later stages.

Existing relevant protocols and tools such as HSAP and RSAT could provide a raft of basic requirements for transboundary EIA for hydropower projects as they are designed to measure social, environmental and economic impacts. RSAT can address key issues of hydropower sustainability, including transboundary impacts of ongoing improvements to practices; basin-wide understanding; integration between basin-planning and hydropower development frameworks; cooperation among riparian countries; equal weighting of socio-economic, environmental and socio-culture factors in hydropower-related decision-making processes; consistent objective of sustainable development across the basin; and engagement stakeholders in all decision-making processes (USAID \& ADB, 2010).

\subsection{Strengthening governance of Mekong River Commission to Enable Win-Win Cooperation}

Since its establishment in 1995, the Mekong River Commission (MRC) is the only intergovernmental agency mandated to focus on water resource management and sustainable development in the LMB. According to the agreement signed by the governments of four riparian countries in 1995, MRC will play a role in basin-wide planning, environmental protection, facilitation of equitable water use and navigation (MRC 1995). Establishment of MRC has broadened the scope of regional cooperation in basin development, resource management, power security, food security and environmental protection and it coordinates and promotes cooperation towards sustainable development as well as management and conservation of water and related resources. Since its formal establishment, MRC contributed initially at the project-scale level and then progressed into strategic planning. Considering the potential negative impacts of hydropower dams on food security, livelihoods and environment, MRC is exploring sustainable options for hydropower development in the region. It has formulated design guidelines for mainstream dams and RSAT and is actively involved in development of the HSAP. MRC also provides guidance for member country decision-making through valuable scientific and strategic research. Despite its long list of achievements MRC faces a number of challenges before an integrated planning approach can be introduced at the basin. Conflicts of interests among riparian countries are a significant barrier to integrated planning; while the primary interest of Thailand and Viet Nam in the Mekong River is as a water source for agriculture, Lao PDR considers the river a primary source of hydropower generation for export, and for Cambodia the Mekong is the main source of fisheries (Gupta, 2005). Unless integrated resource management planning is implemented across the basin, these conflicts will intensify, threatening sustainable development. However, under the current governance structure the MRC can only act as a coordinating advisory body on the water resources of the Mekong Basin and cannot enforce any legally binding agreements that are needed to cover all the development activities occurring in the basin (Tu, 2011). In order to change this, it is vital to establish enabling conditions to realise supranational authority, starting from regional cooperation with benefit sharing among the GMS countries. Reforming the governance structure of MRC with supranational authority would create an enabling environment to allow more involvement in key development decisions across the basin. MRC therefore needs to attain the status of an intergovernmental committee tasked with sustainable development of the Mekong Basin, and be led by the heads or Prime Ministers of the member states. Under the existing MRC governance structure, either water or environment ministers of member countries form the MRC Council and act as Chairpersons of the National Mekong Committee. However, hydropower development in a transboundary river basin has cross-sectoral impacts and is multi-dimensional in nature, including elements of economy, diplomacy and security. Thus, members of the MRC Council under the current governance structure may lack the required authority to take the necessary joint decisions towards sustainable development in the region. By changing the governance structure as proposed above, the Council and National Mekong Committee would have full authority to approve all development projects in the basin so that MRC could play a mediatory role in establishing coherence between country-level development and the regional development framework. However, as discussed in Box 1, in the long-run even the above-mentioned restructuring of MRC governance would not be sufficient if China did not join in. Therefore, 
the ideal approach for sustainable regional cooperation would be to involve all six countries of the Mekong Basin, including China and Myanmar, in the MRC governance structure. In addition, strengthening regional cooperation through the MRC would create enabling conditions to adopt the nascent transboundary EIA framework for the basin and provide win-win solutions for member countries. Consequently, future conflicts on water security, food security and energy security would be prevented.

\section{Conclusions and Policy Recommendations}

It is likely that investment in potential hydropower mainstream dams will be increased in the coming years to fuel regional economic growth. Relatively lax enforcement of environmental controls is one of the reasons behind unsustainable dam construction planning in the basin. Moreover, the hydropower projects, both under construction and planning, do not adequately consider transboundary impacts. The Mekong River is a major source of food and livelihood in the region, but the current or traditional sectoral approach of dam construction does not consider transboundary environmental costs and social costs when estimating net benefits of projects. As a result, food security and the livelihoods of millions of people will be under threat. Early recognition of the nexus between hydropower development and cross-border food security, water security and livelihoods can minimise the risk of diplomatic conflicts and social unrest and is only enabled when member states are willing to divert high-level government priorities from national interests to transboundary interests, as implementing the nexus approach throughout the river basin could contribute to reducing trade-offs between hydropower development and basin-wide socio-economy, and increase synergies through implementation of benefit-sharing mechanisms towards win-win outcomes. In this regard, MRC could play a greater role in the transition to sustainable regional integration in resource security.

In order to facilitate and implement the nexus approach towards sustainable resource security throughout the river basin, it is critical to strengthen the MRC's governance structure. Based on the above discussions the following are our recommendations:

$\checkmark$ Grant MRC supra-national status to realize a common mission and vision for sustainable hydropower development in the region

$\checkmark$ Extend the geographical reach of the MRC to the most upstream countries, including China and Myanmar, to achieve the status of independent transboundary water governance authority in the region. This will ultimately require China and Myanmar to join the MRC, something that appears unlikely at the present time. Member states of the MRC should thus take the initiative in discussions with China and Myanmar governments to set up a timeline in order to ensure they join.

$\checkmark$ Integrate nexus approaches into the resource management and planning frameworks, both at local, national and regional levels so they become normative. Cross-sectoral and planning ministries must play a key role in the promotion of nexus.

$\checkmark$ Promoting nexus smart investment in hydropower projects by introducing safeguarding for people and environmental policies across the river basin. This will help to control commercial investment in unsustainable hydropower projects.

\section{References}

ADBI. (2013). Connecting South Asia and Southeast Asia - Interim Report. A Joint Study of the Asian Development Bank and the Asian Development Bank Institute. Retrieved July 1st, 2016, from $\mathrm{http} / /$ www.adb.org/annual-meeting/2013/kspe/connecting-south-asia-and-southeast-asia

Cambodiadaily. (2013) Villagers Ask Chinese Embassy to Intervene Against Dam Investors. In K. Naren (Eds.). Retrieved July 1st, 2016, from http://www.cambodiadaily.com/archives/villagers-ask-chinese-embassy-to -intervene-against-dam-investors-49144/

Costanza, R., Kubiszewski, I., Paquet, P., King, J., Halimi, S., Sanguanngoi, H., ... Morell, D. (2011). Planning Approaches for Hydropower Development in the Lower Mekong Basin. Institute for Sustainable Solutions, Portland State University, Portland. Retrieved July 1st, 2016, from http://web.pdx.edu/ kub/ publicfiles/Mekong/LMB_Report_FullReport.pdf

Cronin, R., \& Hamlin, T. (2012). Mekong turning point: shared river for a shared future. Mekong turning point: shared river for a shared future. The Henry L. Stimson Centre. Washington DC, USA. Retrieved July 1st, 2016, from http://www.stimson.org/images/uploads/research-pdfs/SRSF_Web_2.pdf

ECA. (2010). The Potential of Regional Power Sector Integration - Greater Mekong Subregion (GMS): Transmission and Trading Case. Prepared by Economic Consulting Associates. Retrieved July 1st, 2016, from 
http://www.esmap.org/sites/esmap.org/files/BN004-10_REISP-CD_Greater\%20Mekong\%20Subregion -Transmission\%20\&\%20Trading.pdf

Fawthorp, T. (2013). Lao dam project raises Mekong fear. Retrieved July 1st, 2016, from http://www.atimes. com/atimes/Southeast_Asia/SEA-01-271113.html

Gapnon L. and Van de Vate, J. F. (1997) Greenhouse gas emissions from hydropower: The state of research in 1996. Energy Policy, 25(1), 7-18. https://doi.org/10.1016/S0301-4215(96)00125-5

GIZ (2014). Case Study - Compensation and Livelihood Restoration at Nam Theun 2 Hydropower Project. Network for Sustainable Hydropower Development in the Mekong Region. Published by GIZ. Retrieved July 1st, 2016, from http://www.cdri.org.kh/shdmekong/casestudy/1Nam_Theun\%202_Laos_Silinthone final.pdf

GoL. (2016). History of hydropower in Lao PDR. Department of Energy Promotion and Development, Ministry of Energy and Mines. Retrieved June 23, 2016, from www.poweringprogress.org/index.php?option $=$ com_content $\&$ view $=$ article $\&$ id $=88 \&$ Itemid $=126$

Griggs, D. (2013). Sustainable development goals for people and planet. Nature, 495, 305-307, Macmillan Publishers Limited. Retrieved July 1st, 2016, from http://sustainabledevelopment.un.org/content/ documents/844naturesjournal.pdf

Grimsditch, M. (2012). 3S Rivers Under Threat - Understanding New Threats and Challenges from Hydropower Development to Biodiversity and Community Rights in the $3 S$ river Basin. Published by $3 S$ Rivers Protection Network \& International Rivers. Retrieved July 1st, 2016, from

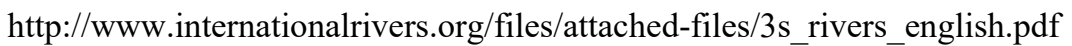

Grumbine, R.; Dore, J., \& Xu, K. (2012). Mekong hydropower: Drivers of change and governance challenges. Frontiers in Ecology and the Environment, 10(2), 91-98. https://doi.org/10.1890/110146

Gupta, A. D. (2005). Challenges and opportunities for integrated water resources management in Mekong river basin. In the Proceedings of the International Symposium entitled "Role of Water Sciences in Transboundary River Basin Management" held from, 10-12nd March 2005, Ubon Ratchathani, Thailand.

Herbertson, K. (2013). Xayaburi Dam: How Laos Violated the 1995 Mekong Agreement. Published by International Rivers. Retrieved July 1st, 2016, from_http://www.internationalrivers.org/files/attached-files/ intl_rivers_analysis_of_mekong_agreement_january_2013.pdf

ICEM. (2010). MRC Strategic Environmental Assessment (SEA) of hydropower on the Mekong mainstream. Final Report. International Center for Environmental Management, Hanoi, Vietnam.

IEA. (2010). Energy technology Perspective, scenarios and strategies to 2050, In support to the G8 plan of action.

IES (Intelligent Energy Systems). (2016). Alternatives for power generation in the Greater Mekong Subregion. Volume 1: Power Sector Vision for the Greater Mekong Subregion. Retrieved July 1st, 2016, from http://awsassets.panda.org/downloads/regional.pdf

International Rivers. (2014). Xayaburi Dam. Retrieved July 1st, 2016, from http://www.internationalrivers.org/ campaigns/xayaburi-dam

King, P., Bird, J., \& Haas, L. (2007). The Current Status of Environmental Criteria for Hydropower Development in the Mekong Region - Technical Report. Consultant's Report to the Asian Development Bank, Mekong River Commission Secretariat and World Wildlife Fund (WWF). Worldwide Fund for Nature. Retrieved July 1st, 2016, from http://www.wwf.or.th/en/publications/publications/?101900/ Environmental-Criteria-for-Hydropower-Development-in-the-Mekong-Region

Kinna, R. (2016). An alternate past/future for Mekong River dams under the UN Watercourses Convention: Part 1. Published by Global Water Forum. Retrieved July 1st, 2016, from http://www.globalwaterforum.org/ 2016/04/04/an-alternate-pastfuture-for-mekong-river-dams-under-the-un-watercourses-convention-part-1/

Klare, M. T. (2001). The New Geography of Conflict. Foreign Affairs, 80(3), 49-61. https://doi.org/10.2307/ 20050150

Kumar, M. D., Bassi, N., Narayanamoorthy, A., \& Sivamohan, M. V. K. (2014). The Water, Energy and Food Security Nexus: Lessons from India for Development. Published by Earthscan from Routledge. 
Kummu, M., \& Varis, O. (2007). Sediment-related Impacts due to Upstream Reservoir Trapping, the Lower Mekong River. Geomorphology, 85, 275-293. https://doi.org/10.1016/j.geomorph.2006.03.024

Lele, U., Klousia-Marquis, M., \& Goswami, S. (2013). Good governance for food, water and energy security. Aquatic Procedia, (1), 44-63.

Marwaan, M. (2014). Lao dam troubles Mekong waters. The Irrawaddy: May 2014. Retrieved July 1st, 2016, from http://www.irrawaddy.org/asia/magazine-regional/lao-dam-troubles-mekong-waters.html

Matsui, S., Keskinen, M., Sokhem, P., Nakamura, M. (2006). Tonle Sap - Experience and Lessons Learned Brief. Published online by LakeNet's World Lakes Website. Retrieved July 1st, 2016, from http://www.worldlakes.org/uploads/25_Lake_Tonle_Sap_27February2006.pdf

Matthews, N. (2012). Water grabbing in the Mekong basin - An analysis of the winners and losers of Thailand's hydropower development in Lao PDR. Water Alternatives, 5(2), 392-411.

MRC. (1995). Agreement on the cooperation for the sustainable development of the Mekong river basin -5 th April 1995. Mekong River Commission (MRC). Retrieved July 1st, 2016, from http:/www.mrcmekong.org/assets/Publications/policies/agreement-Apr95.pdf

MRC. (2011). Knowledge Base on Benefit Sharing. Volume 1 of 5, Summary and Guide to the Knowledge Base (KB) Compendium (Version 1). MRC Initiative on Sustainable Hydropower. Mekong River Commission. Retrieved July 1st, 2016, from http://www.mrcmekong.org/assets/Publications/Manuals-and-Toolkits/ knowledge-base-benefit-sharing-vol1-of-5-Jan-2012.pdf

NIC. (2012). Global Trends 2030: Alternative Worlds. A Publication of the National Intelligence Council (NIC)-United States of America. Retrieved July 1st, 2016, from http://www.dni.gov/nic/globaltrends

Phnompenh Post. (2014). Xayaburi dam 30\% finished, says Laos. Retrieved July 1st, 2016, from http://www.phnompenhpost.com/national/xayaburi-dam-30-finished-says-laos

Qaddumi, H. (2008). Practical approaches to transboundary water benefit sharing. Working Paper 292. Overseas Development Institute (ODI)

Rasul, G. (2016). Managing the food, water, and energy nexus for achieving the Sustainable Development Goals in South Asia. Environmental Development, 18, 14-25. https://doi.org/10.1016/j.envdev.2015.12.001

Rossouw, N. (2010). Benefit sharing with local impacted communities during project implementation Overview of the literature and practical lessons from the Berg River Dam. Retrieved July 1st, 2016, from http://www.cdri.org.kh/shdmekong/12.Berg_Benefit\%20sharing.pdf

Sadoff, C.W. and Grey, D. (2002). Beyond the River: The Benefits of Cooperation on International Rivers. Water Policy, 4(5), 389-403. https://doi.org/10.1016/S1366-7017(02)00035-1

Smajgl, A., Ward, J. R., Foran, T., Dore, J., \& Larson, S. (2015). Visions, beliefs, and transformation: exploring cross-sector and transboundary dynamics in the wider Mekong region. Ecology and Society, $20(2), 15$. http://dx.doi.org/10.5751/ES-07421-200215

Sneddon, C., \& Fox, C. (2008). River basin politics and the rise of ecological and transnational democracy in Southeast Asia and Southern Africa. Water Alternatives, 1(1), 66-88.

Thanhnienews. (2016). Laos speeds up hydropower plant on Mekong River despite concerns. Retrieved July 1st, 2016, from http://www.thanhniennews.com/society/laos-speeds-up-hydropower-plant-on-mekong-river -despite-concerns-63365.html

Thanhniennews. (2011). And easy flows the Mekong. Retrieved July 1st, 2016, from http://thanhniennews.com/special-report/and-easy-flows-the-mekong-12628.html

Tu, D., T. (2011). A Vietnamese Perspective on Proposed Mainstream Mekong Dams. A short discussion paper published by STIMSON. Retrieved July 1st, 2016, from http://www.stimson.org/summaries/avietnamese-perspective-on-proposed-mainstream-mekong-dams/

Vannarith, C. (2012). A Cambodian Perspective on Mekong River Water Security. Retrieved July 1st, 2016 , from http://www.stimson.org/summaries/a-cambodian-on-mekong-river-water-security/

Vietnamnet. (2016). Vietnam needs master plan for water sources: expert. Retrieved from http://english.vietnamnet.vn/fms/environment/162477/vietnam-needs-master-plan-for-water-sources--expert .html 
Wolf, A. T., Yoffe, S. B., \& Giordano, M. (2003). International Waters: Identifying Basins at Risk. Water Policy, $5,29-60$.

WWF. (2011). Critical review of the PÖYRY compliance report about the Xayaburi dam and the MRC design guidance - Fish and fisheries aspect. World Wildlife Fund (WWF). Retrieved July 1st, 2016, from http://awsassets.panda.org/downloads/review_of_fisheries_aspects_in_the_poyry_report.pdf

WWF. (2014). Don Sahong Dam Brief - Very high risk for Cambodia. Published by World Wildlife Fund (WWF) in February 2014. Retrieved July 1st, 2016, from http://awsassets.panda.org/downloads/don _sahong_brief__final_05feb.pdf

Zaffos, J. (2014). Life on Mekong Faces Threats as Major Dams Begin to Rise. Retrieved July 1st, 2016, from https://e360.yale.edu/mobile/feature.msp?id=2741

Ziv, G., Baran, E., Nam, S., Rodríguez-Iturbe, I., \& Levin, S. A. (2012). Trading-off fish biodiversity, food security and hydropower in the Mekong River Basin, Proceedings of the National Academy of Sciences, 109(15), 5609-5614. Retrieved from http://www.pnas.org/content/109/15/5609.full

\section{Copyrights}

Copyright for this article is retained by the author(s), with first publication rights granted to the journal.

This is an open-access article distributed under the terms and conditions of the Creative Commons Attribution license (http://creativecommons.org/licenses/by/4.0/). 